\title{
ІНСТРУМЕНТИ ФІНАНСОВОГО РИНКУ ТА ЇХ КЛАСИФІКАЦІЯ В УМОВАХ ЦИФРОВІЗАЦІЇ СУСПІЛЬСТВА
}

\author{
Кравченко Анна Станіславівна \\ кандидат економічних наук, доцент \\ ДВНЗ «Університет банківської справи» (м. Львів, Україна) \\ ORCID: 0000-0003-1977-8181 \\ vovchak.olga@meta.ua
}

Досліджено інструменти фрінансового ринку та їх класифікацію в умовах цифрровізації суспільства, зокрема проаналізовано та уточнено дефініцію «фінансовий інструмент», «цифровий фрінансовий інструментп, оцінено та побудовано модель інструментальної класифікації фінансового ринку за його сегментами.

Ключові слова: інструменти фрінансового ринку, класифікація інструментів фінансового ринку в умовах цисрровізації суспільства, фінансовий інструмент, иифрровий фінансовий інструмент, модель інструментальної класифікації фінансового ринку за його сегментами.

DOl: https://doi.org/10.32845/bsnau.2019.4.2

Постановка проблеми. В світовому фінансовому просторі, набувають розповсюдження, процеси глобалізації та цифровізації, основною передумовою, яких є забезпечення фінансового ринку ефективними інструментами. Розвиток економіки України, залежить від належного функціонування національного фінансового ринку, відповідна тенденція формуватиметься в разі створення оптимальної системи взаємозв'язків, щодо обігу якісних фінансових інструментів. Тому, проблематика розвитку фінансово-економічних процесів, за умови забезпечення якісного інструментарію фінансового ринку, потребує дослідження їх сучасних проявів, сутнісних та класифікаційних ознак.

Аналіз основних досліджень та публікацій. Вивченню питань фінансових інструментів, зокрема цифровізації (окремі автори) займались: Н. Негропонте, Ю. Колобов, В. Міщенко, С. Науменкова, І. Абрамова, Л. Шкварчук тощо, проте незважаючи на існуючу кількість публікацій за науковою тематикою, питання інструменти фінансового ринку та їх

класифікація в умовах цифровізації суспільства не достатньо досліджені та потребують подальшого розвитку.

Постановка завдання. Мета дослідження - дослідити та побудувати модель інструментальної класифікації фінансового ринку за його сегментами. Методика (методологія) дослідження - для уточнення та побудувати моделі інструментальної класифікації фінансового ринку, застосовано системний, комплексний, синергетичний, кібернетичний підходи, методи групування, аналізу, синтезу, моделювання, абстрактно-логічний.

Виклад основного матеріалу. Світова цифрова фінансіалізація охоплює економічні процеси, зокрема об'єкти, інструменти фінансового ринку. Слушно, уточнити фінансові інструменти та їх класифікацію в цифррових умовах.

Вчені, застосовують різні підходи для розкриття сутності поняття «фінансовий інструмент» табл.1.

Літературний аналіз дефрініції «фінансовий інструмент»

\begin{tabular}{|c|c|c|}
\hline Вчений & Сутність поняття «фінансовий інструмент» & Науковий підхід \\
\hline $\begin{array}{l}\text { Ю.Колобов, В.Міщенко, } \\
\text { С.Науменкова }\end{array}$ & $\begin{array}{l}\text { будь-який контракт, в результаті якого створюється фінансовий актив, відповідно у одного } \\
\text { суб'єкта господарювання та фінансового забов'язання у іншого суб'єкта господарювання } \\
\text { [2, с. } 456]\end{array}$ & Нормативний \\
\hline О. Сохацька & $\begin{array}{l}\text { інструменти, що забезпечують отримання доходу, а також діють, як цінні папери та } \\
\text { контракти }[4, \text { с. } 684]\end{array}$ & $\begin{array}{r}\text { Інструментально- } \\
\text { функціональний }\end{array}$ \\
\hline $\begin{array}{l}\text { Д. Дема, І. Абрамова, } \\
\text { Л. Недільська }\end{array}$ & $\begin{array}{l}\text { різні фінансові контракти, що обертаються на ринку і мають свою грошову вартість та за } \\
\text { допомогою яких проводяться операції на фрінансовому ринку [1, с. 27] }\end{array}$ & $\begin{array}{l}\text { Нормативно- } \\
\text { ринковий }\end{array}$ \\
\hline Л. Шкварчук & $\begin{array}{l}\text { специфічний актив, що представляє вимоги його власника на отримання фінансової } \\
\text { винагороди в майбутньому [5, с. 34] }\end{array}$ & $\begin{array}{l}\text { Інструментально- } \\
\text { нормативний }\end{array}$ \\
\hline Я. Петраков & $\begin{array}{l}\text { фінансові документи, що призводять до зростання обсягів грошових коштів і отримання } \\
\text { кумулятивного прибутку реципієнтами, продуцентами [3, с. 237] }\end{array}$ & $\begin{array}{c}\text { Нормативно- } \\
\text { функціональний }\end{array}$ \\
\hline Я. Дропа & $\begin{array}{l}\text { продукт фінансового ринку у вигляді договору, для отримання прибутку від фінансової } \\
\text { операції, або залучення фінансових ресурсів [4, с. 684] }\end{array}$ & $\begin{array}{l}\text { Нормативно- } \\
\text { інструментальний }\end{array}$ \\
\hline В. Клименко & $\begin{array}{l}\text { контракти, які визначають права, вимоги, участь, щодо отримання доходу в майбутньому } \\
{[6, \text { с. } 15]}\end{array}$ & Нормативний \\
\hline В. Оспіщев & інструменти, що обертаються на ринку [8, с. 362 -363] & Ринковий \\
\hline О. Зайцев & $\begin{array}{l}\text { документи фрінансових взаємовідносин, щодо участі у фінансових операціях; засоби для } \\
\text { виконання завдань фінансової політики [10, с. 10] }\end{array}$ & $\begin{array}{l}\text { Нормативно- } \\
\text { інструментальний }\end{array}$ \\
\hline C. Еш & інструмент передачі фінансових ресурсів між учасниками ринку [7, с. 37] & Інструментальний \\
\hline В. Шелудько & $\begin{array}{l}\text { не речьові активи, щодо законних вимог їх власників на отримання майбутнього } \\
\text { грошового доходу [9], }[7, \text { с. 36-37] }\end{array}$ & $\begin{array}{l}\text { Інструментально- } \\
\text { нормативний }\end{array}$ \\
\hline $\begin{array}{l}\text { І. Боярко, } \\
\text { Л. Гриценко }\end{array}$ & $\begin{array}{l}\text { документи, що мають грошову ціну та можуть придбаватися та продаватися } 3 \\
\text { економічною вигодою }[11, \text { с. 261] }\end{array}$ & $\begin{array}{l}\text { Нормативно- } \\
\text { ринковий }\end{array}$ \\
\hline
\end{tabular}
`Джерело: власне дослідження 
Найбільш вживаним науковим підходом є нормативно-інструментальний. Проте, авторські тлумачення та нормативно-правові акти не змістують комплексно, системно, з урахування сучасних суспільних тенденцій, щодо розкриття терміну. Тому, виникає необхідність уточнити сутність поняття «фінансовий інструмент», «цифровий фінансовий інструмент».

Отже, фінансовий інструмент - це економічна категорія, що змістує компонентою економіко-правових взаємовідносин суб'єктів фінансового ринку для отримання кумулятивного фінансового ефекту від проведених операцій.
Цифровий фінансовий інструмент - це фінансово-кібернетична категорія, що формується, обертається в кіберпросторі, має не директивну, економіко-правову цінність та забезпечує цифровий фінансовий ефект суб'єктам цифровізованого фінансового ринку.

В свою чергу, науковці розкриваючи різни ознаки, класифікаційних елементів, щодо розкриття видів фінансових інструментів табл.2. Проте, комплексність, системність, врахування цифровізації суспільних процесів, на належному рівні, в дослідженнях класифікації фрінансових інструментів не прослідковується.

Аналіз літературної класифікації фінансових інструментів

\begin{tabular}{|c|c|c|c|c|c|c|c|c|c|c|}
\hline Ознаки, класифікаційні елементи & $\begin{array}{l}\text { 믐 } \\
\text { 음 } \\
\text { ᄄ }\end{array}$ & 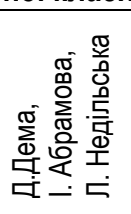 & 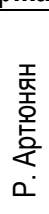 & 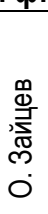 & 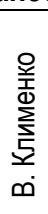 & 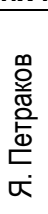 & 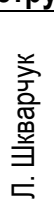 & 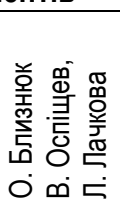 & 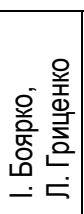 & 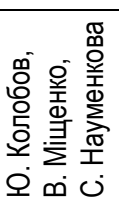 \\
\hline $\begin{array}{l}\text { За секторами фінансового ринку (за різними } \\
\text { авторськими компонентами) }\end{array}$ & & & & + & + & & + & + & + & \\
\hline За видом фінансового забов'язання & & & & & & + & + & + & & \\
\hline За основними та похідними інструментами & & + & + & & + & & & & & \\
\hline За видами обліку & & & & & & + & + & & & \\
\hline За строком обігу & & & & & & & & + & & \\
\hline За видом гарантій & & & & & & & + & + & & \\
\hline За видом ризику & & & & & & & + & + & & \\
\hline За видом значущості & & & & & & & + & + & & \\
\hline За видом державних інструментів & + & & & & & & & & & \\
\hline Інші & + & & & & & & + & & & + \\
\hline
\end{tabular}

`Джерело: власне дослідження

Вченими, найбільш вживано, такий поділ класифікаційних елементів фінансових інструментів, як: за секторами фінансового ринку (за різними авторськими компонентами); за видом фінансового зобов'язання; за основними, а також похідними інструментами. Однак, такі класифікації, потребують уточнення, в комплексно-цілісному, системному, синергетичному аспектах.

Існує необхідність уточнення класифікації фінансових інструментів основних сегментів фінансового ринку, з урахуванням цифрових суспільних процесів.

Отже, дослідження функціонування структурних еле- ментів фінансового ринку, сучасних тенденцій цифрровізації суспільства, сутнісних та функціональних, особливостей характеристик фінансових інструментів, дозволило побудувати, уточнену модель класифікації інструментів фінансового ринку за основними його сементами (рис.1): валютним, кредитним, грошовим, фрондовим, страховим, ринком цифррових фрінансових активів, дорогоцінних металів, ОТС, біржовим строковим фінансовим ринком.

Така модель, слугує уточненою прикладною схемою суб'єктно-об'єктних економічних відносин на фінансовому ринку. 
Модель інструментальної класифікації

фінансового ринку за його сегментами
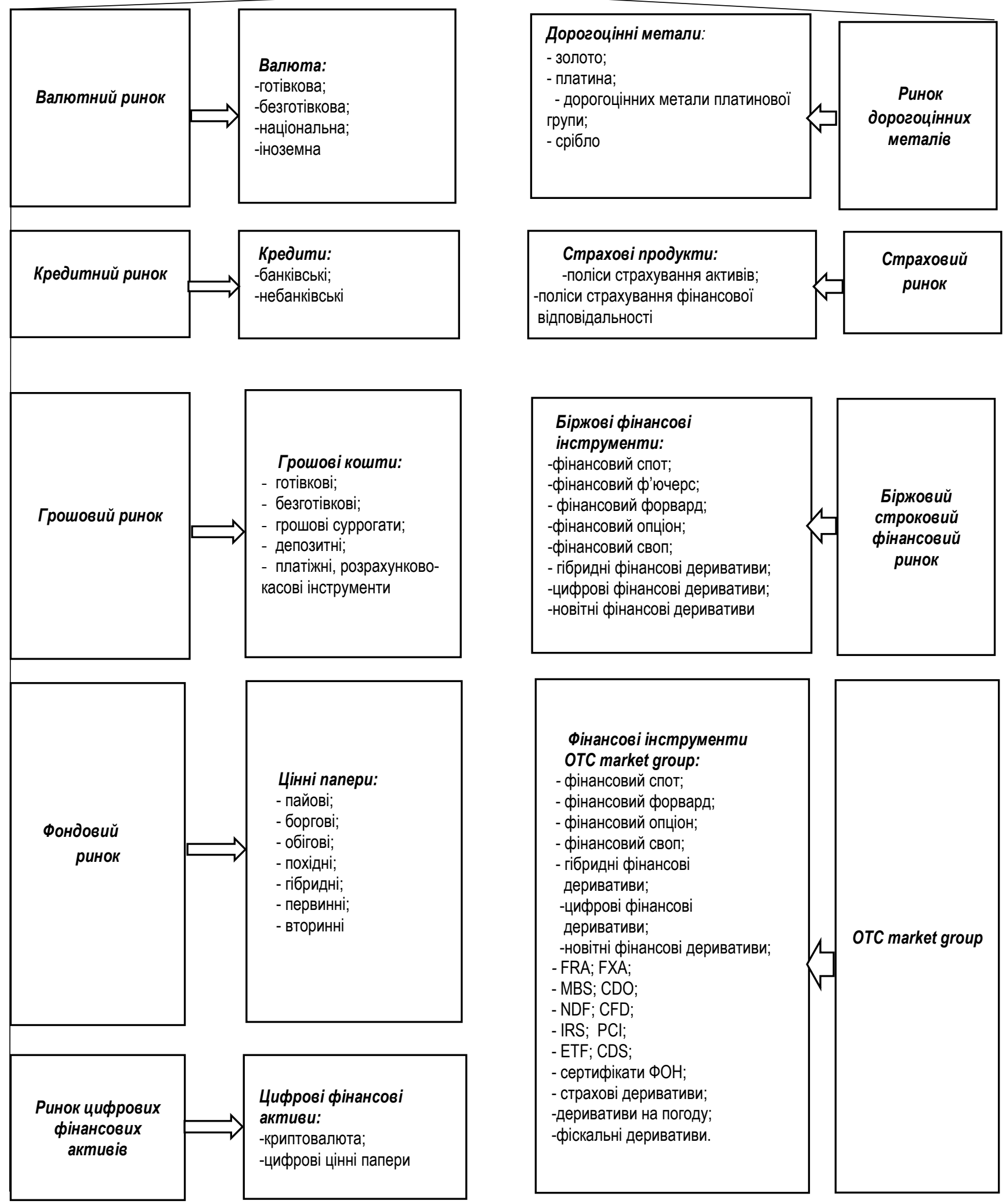

\section{Біржові фінансові} інструменти:

-фінансовий спот;

-фрінансовий ф'ючерс;

- фінансовий форвард;

-фінансовий опціон;

-фрінансовий своп;

- гібридні фінансові деривативи;

-цифрові фрінансові деривативи;

-новітні фінансові деривативи

Біржовий

строковий

фінансовий

ринок

Фінансові інструменти

OTC market group:

- фінансовий спот;

- фінансовий форвард;

- фінансовий опціон;

- фінансовий своп;

- гібридні фінансові

деривативи;

-цифрові фінансові

деривативи;

-новітні фінансові деривативи;

- FRA; FXA;

- MBS; CDO

- NDF; CFD;

- IRS; PCl;

- ETF; CDS;

- сертифікати ФОН;

- страхові деривативи;

-деривативи на погоду;

-фріскальні деривативи.

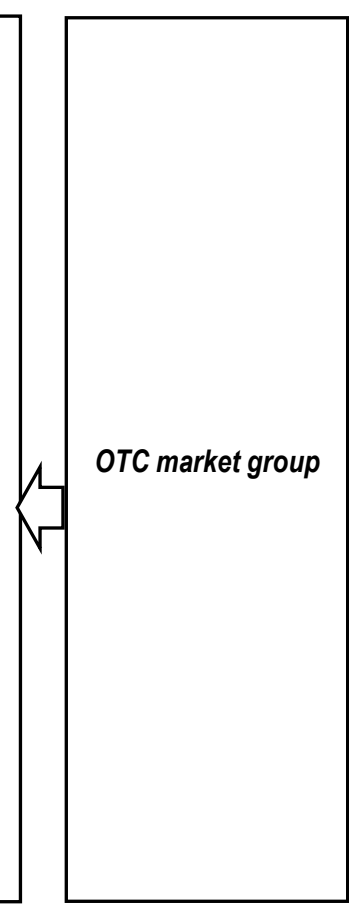

Рис.1. Модель інструментальної класифікації фінансового ринку 
Висновки. Фінансові інструменти, слугують, забезпеченням виконання функцій фрінансового ринку, а отже задоволенням економічних потреб фінансових суб'єктів, що впливає на підвищення рівня ділової активності та привабливості національного фінансового сектору на світовій арені. Тому, від їх актуальності і розробленості залежить розвиток, інноваційність та інтеграційність вітчизняних фінансових процесів в світовий простір.

\section{Список використаної літератури:}

1. Дема Д.І. Фінансовий ринок: навч. посіб. / Д.І. Дема, І.В. Абрамова, Л.В. Недільська. - Житомир: ЖНАЕУ, 2017. $448 \mathrm{c}$.

2. Арбузов С.Г. Банківська енциклопедія / С.Г. Арбузов, Ю.В. Колобов, В.І. Міщенко, С.В. Науменкова. - К.: ЦНД НБУ, 2011. - 504 c.

3. Петраков Я.В. Фінансові інструменти: сутність та класифікація // Науковий вісник Полісся. Фінанси. Банківська справа/Я.В. Петраков-3.-2016.- С.235-240.

4. Дропа Я.Б. Гроші фрінанси і кредит // Журнал МНУ ім. В.О. Сухомлинського/ Я.Б. Дропа -16.- 2017. - С. $682-687$.

5. Шкварчук Л.О. Фінансовий ринок : навч. посіб. / Л. О. Шкварчук. - К.: Знання, 2013. - 382 с.

6. Клименко В.В. Фінансовий ринок: навч. посіб. / В.В. Клименко, Л.М. Акімова, Л.М. Докієнко. - К.: ЦУЛ, 2015. - 358 с.

7. Еш С.М.Фінансовий ринок: навч. посіб. / Еш С.М. - К.: ЦУЛ, 2011.-528 с.

8. Крутова А.С. Фінанси: навч. посіб. / Крутова А.С., Близнюк О.П., Лачкова Л.І. та ін. - Х.: Лідер, 2013. - 560 с.

9. Шелудько В.М. Фінансовий ринок: навч. посіб./ Шелудько В.М.-К.: Знання-прес, 2003. - 535 с.

10. Зайцев О.В. Основи фінансового інструментарію: підруч. / О.В. Зайцев. - Суми: СДУ, 2016. - 523 с.

11. Боярко І. М. Інвестиційний аналіз: навч. посіб. / Боярко І. М., Гриценко Л. Л. - К.: ЦУЛ, 2011. - 400 с.

12. Кравченко А.С. Сутність дефініції «фінансовий дериватив» та їх обіг на біржовому фондовому ринку// Науковий вісник НУБіП / Кравченко А.С.- 2018. - Вип.284.- С.104-109.

Kravchenko A.S., PhD, Associate Professor, Banking University Lviv Institute (Lviv, Ukraine)

Financial market instruments and their classification in the conditions of digitalization of the society

Financial market instruments and their classification in the conditions of digitalization of society are investigated, in particular the definition of «financial instrument», "digital financial instrument» is analyzed and refined, the model of instrumental classification of the financial market by its segments is evaluated and constructed.

Key words: financial market instruments, classification of financial market instruments in the conditions of digitalization of society, financial instrument, digital financial instrument, model of instrumental classification of financial market by its segments.

Дата надходження до редакції: 25.11.2019 р. 